\title{
CONDITIONS OF INDIVIDUAL ENTREPRENEURSHIP IN THE OPINION OF THE INHABITANTS OF LUBLIN
}

\author{
Elena MIESZAJKINA \\ Katedra Zarządzania, Politechnika Lubelska, Lublin; e.mieszajkina@pollub.pl
}

\begin{abstract}
The article discusses issues related to individual entrepreneurship. It is conditioned by a series of external (economic, political-legal, socio-cultural) and internal (individual characteristics) factors. The results of research conducted on the group of inhabitants of Lublin were presented in order to determine the factors which facilitated and hindered the establishment of one's own company. Starting up individual business activity is mainly facilitated by internal factors, while external factors make this process difficult.
\end{abstract}

Keywords: individual entrepreneurship, conditions of entrepreneurship.

\section{Individual entrepreneurship}

Entrepreneurship is a multidimensional concept covering a broad spectrum of issues. Entrepreneurial attitudes and behaviours, opportunities identification, using opportunities and the launch of new ventures, running a company and managing it to develop, implementing innovation, acting on its own, in a team or within an organisation, creating new values in different socio-economic spheres - these are just some of its aspects.

Individual entrepreneurship is when a business is undertaken by an individual on his or her own account and at his or her own risk, and he or she runs a business. This is the most discussed and analysed type of enterprise. S. Sudoł writes that the term "entrepreneurship" is primarily related to a single person, regardless of the circumstances concerning him/her, such as age, sex, nationality, education, occupation, or place in the social structure (Sudol, 2008, p. 11). An individual entrepreneur runs his or her own business, bears all the responsibility (including financial) and risks associated with it, but also has all the benefits and profits. He or she should have relevant knowledge in all areas related to business activities (management, production, marketing, finance, logistics, etc.).

There are three groups of entrepreneurs who decide to start an individual business:

1) people who want to build a company from scratch, develop it by hiring employees, buying fixed assets, earn a living in that way and they derive professional satisfaction 
(classic entrepreneurs). They set up a business primarily to make a profit. It is important for them to develop the company, to increase its potential and value; to achieve these goals they are able to give up their personal plans and dreams,

2) persons wishing to carry out their activity as a freelance profession for many clients using the freedom afforded by independent work organisation (lifestyle of an entrepreneur). Their key distinction is that they are motivated mainly by the desire to realise their dreams, vision, passion, and not a profit. They usually seek independence, sometimes they devote the development of activities for the realisation of their personal plans,

3) people who have switched from a full-time job to their own business, and the recipient of their company's services is the former employer (outsourcing entrepreneurs). They largely decide on how to do their tasks, so they can show more creativity and apply their ideas to organise their work, to cooperate with other entrepreneurs.

Ch. Karlsson, B. Johansson and R.R. Stough stresses that the motives of individual entrepreneurs from all three groups are not entirely different, but may be a mixture of economic and non-economic motives (Karlsson, Johansson, and Stough, 2014, p. 140-146). On the one hand, they perform management functions in the organisation, at the same time being its owners or co-owners, so they are capitalists - they get a return on their invested capital. On the other hand, as entrepreneurs-creators of new ideas, they should be rewarded for their initiation and implementation. In practice, however, it is impossible to separate these two roles (Gruszecki, 2002, p. 197).

Entrepreneurship is the result of the interaction of three variables: the ability to see people's opportunities, motivation and the chance to use that opportunity, and the environment in which they operate. Particular emphasis should be placed on the role of the last one. The external context has a significant impact on the willingness of people to engage in entrepreneurship, because they have to cope with innumerable conditions created by the environment.

Poland belongs to quite enterprising countries, characterised by a high percentage of entrepreneurs $(15 \%)$ and people intending to start their own company in the next 3 years $(20 \%)$, and a positive assessment of their own qualifications to establish their own company (56\%). These results are above the EU average. On the other hand, Poland is less attractive in terms of European entrepreneurship when it comes to perceiving market opportunities for starting a business within the next 6 months at home. The dynamics of Polish entrepreneurship is still relatively high, and every year hundreds of thousands of people join the business circle. In this respect Poland is in the EU top (Tarnawa, and Skowrońska, 2016, p. 38-42). 


\section{The determinants of individual entrepreneurship}

Entrepreneurship determinations create forces that are conducive to strengthening the entrepreneurial process and its results, and those that inhibit the process (Lichtarski, and Karaś, 2003, p. 23). They are often classified as external and internal, but their interactions are emphasised (Kraśnicka, 2002, p. 105-119; Piecuch, 2013, p. 82-111; Safin, 2003, p. 14). The most important external factors are environmental factors - economic, political-legal, and socio-cultural.

Economic conditions/factors are related to the functioning of mechanisms and market instruments. E. Rollnik-Sadowska divides them into three types: macroeconomic, concerning the labour market and workforce, and microeconomic (Rollnik-Sadowska, 2010, p. 27-38). Economic freedom (manifested in freedom of setting up a business activity and running a business), economic policy of the state, ownership structure of the economy, existence of a competitive market, stability of the financial, tax, and banking systems etc. contribute to the creation of entrepreneurial behaviours of entrepreneurs and citizens (Jędruchniewicz, 2011, p. 18-23).

Socio-cultural factors include a system of norms, beliefs, and traditions that apply in a given society. They contribute to the shaping of certain values related to prospective or retrospective orientation, competences or connections, individualism or collectivism, freedom of expression or trust, rigor of the code of ethics, or relaxation (Glinka, 2008, p. 10-14; Gołębiowski, 2008, p. 27-38; Rollnik-Sadowska, 2010, p. 40-46). In progressive and development cultures, the configuration of these values contributes to the modelling and empowerment of entrepreneurial attitudes. "Culture is the foundation upon which society operates in all its aspects. It is the basis of social life, which is the basis of the economic system, and consequently the development of entrepreneurship" according to R. Majkut (Majkut, 2014, p. 137).

Political and legal conditions create the assumptions of economic policies implemented by state and local authorities, the accepted ideology of governance, the efficiency of public institutions, the legal system, and the justice system. As entrepreneurship develops in a specific institutional and legal environment, these factors need to be stressed; they are the basis of all self-employment activity (Majkut, 2014, p. 100-123; Rollnik-Sadowska, 2010, p. 21-27). The role of the state is emphasised in a special way. It differs depending on the objectives set and the economic and social determinants - from inhibiting the development of entrepreneurship, through indifferent observation, to actively supporting it, and acceleration.

L.H. Haber adds another dimension - communicative, connected with the influence of the mass media (television, press, radio, Internet). With their help, from the local to global community, positive business models are promoted, examples to follow, educational and advisory information (Haber, 1996, p. 17). 
The environment can create opportunities encouraging and facilitating entrepreneurial actions, as well as barriers, discouraging and hindering these actions. The need for observation of the environment by the entrepreneur is raised by J. Penc: the environment should be continually monitored, information on possible changes and tendencies in the environment should be collected and processed in order to be able to take full advantage of emerging opportunities, succeed in the marketplace and, if possible, also a competitive advantage (Penc, 2001, p. 180).

Internal factors in the case of individual entrepreneurship are dealt with by individual features, personal features of an entrepreneur such as personality characteristics, motives, value systems, knowledge, creativity, etc. T. Piecuch emphasises that it is not easy to quantify and verify them. The features that impede entrepreneurial activity include: submission, isolation from others, laziness, pessimism, difficulty in making decisions, concerns and fears, and a lack of mental immunity and vital energy. The facilitating features are: independence, ability to work with people, need for achievement, consistency in action, decisiveness, mental immunity, ability to work in difficult situations, intuition, vitality, creativity, and innovation. They should be the subject of specific analysis, because they often turn out to be decisive since they are "an important intangible force, an incentive, and a facilitator of the entrepreneurial initiative" (Piecuch, 2013, p. 86).

Entrepreneurship determinants are not universal in relation to the whole country. K. Zieliński draws attention to the need for analysing regional factors (Zieliński, 2014, p. 4144). The Lublin Province since 2011 is on the penultimate, $15^{\text {th }}$ place in annual rankings developed by the Polish Agency for Enterprise Development (PARP) (Tarnawa, and Skowrońska, 2016, p. 49). The city of Lublin is better off than the rest of the region. It should be noted, however, that for the development of entrepreneurship there are good conditions. They are created by a wealth of knowledge that allows for building a knowledge-based economy, intangible assets, new technologies, and especially human capital. Lublin is characterised by a good level of general education of the inhabitants and the qualifications of staff, developed higher education facilities, high scientific and research potential, relatively low labour costs, favourable geographic position on major transport routes linking Western and Eastern Europe (Mieszajkina, 2014, p. 53-61). However, it is perceived as a slightly peripheral city, attracting little interest of investors. Improving its image and competitiveness is possible through the development of entrepreneurship, active involvement of governments, business support organisations, and residents in the process. 


\section{Factors conducive to and hindering the establishment of one's own company in the opinion of Lublin residents}

What encourages and what hinders the inhabitants of Lublin in establishing their own company? In order to answer this question, a survey was conducted between February and April 2015. The selection of the test sample was a deliberate quota sampling ${ }^{1}$. Residents of Lublin, conducting their own business activity or employed on a permanent basis were asked to fill in the questionnaire survey. The structure of people employed in the public and private sectors in the Lublin Province were considered: public and private sector (employed persons) - 73.1\%, private sector: employers and self-employed - 26.9\% (Aktywność..., 2015, p. 7). 100 questionnaires were distributed - 73 to employees and 27 - to business owners. 99 completed questionnaires were returned, of which 10 were rejected due to significant deficiencies in the answers provided. As a result, information from 89 respondents was used for the analysis. 24 persons (27\%) are self-employed, $73 \%$ are full-time employed. The study involved 46 women and 43 men. These were mostly young people - 50 people aged 21-30, 19 people aged 31-40, 11 people aged 41-50 years and 9 people over 50 years old. The predominant participation of young people is due to the fact that most often young people start their own businesses. Possession of a Master's degree was declared by 36 respondents, bachelors or engineering -18 , meddle -35 .

The respondents were asked about the characteristics they think should characterise entrepreneurs and their degree of ownership. The ratings ranged from 1 to 5, where 1 means little importance, and 5 - high importance. The answers are included in Table 1.

Table 1.

Personality features of entrepreneurs

\begin{tabular}{|l|c|c|}
\hline \multirow{2}{*}{\multicolumn{1}{|c|}{ Feature }} & \multicolumn{2}{c|}{ average degree/level } \\
\cline { 2 - 3 } & $\begin{array}{c}\text { Degree/level of } \\
\text { importance }\end{array}$ & $\begin{array}{c}\text { Degree/level of } \\
\text { importance }\end{array}$ \\
\hline Diligence & 4.66 & 4.33 \\
\hline Optimism & 4.12 & 3.75 \\
\hline Ability to use emerging opportunities & 4.27 & 3.45 \\
\hline Perseverance & 4.61 & 3.96 \\
\hline Creativity & 4.45 & 3.74 \\
\hline Ability to take risks & 4.27 & 3.34 \\
\hline Honesty & 4.26 & 4.46 \\
\hline Self-confidence & 4.36 & 3.99 \\
\hline High professionalism & 3.99 & 3.92 \\
\hline Tendency to charity & 3.28 & 3.87 \\
\hline Insistence in pursuit of the goal & 4.40 & 3.99 \\
\hline
\end{tabular}

\footnotetext{
${ }^{1}$ Quota sampling is based on knowledge of the general population structure. Samples that meet the desired characteristics are selected in such a way that their distribution in the sample corresponds to the distribution of these characteristics in the general population (http://www.bbm.com.pl/metodologia-badawcza/metodydoboru-proby-badawczej/. Available online 25.06.2015).
} 


\begin{tabular}{|l|c|c|}
\hline Independence & 3.66 & 3.91 \\
\hline The desire to get rich & 3.22 & 3.24 \\
\hline Manifesting the initiative & 4.06 & 3.72 \\
\hline Ability to work with people & 4.60 & 4.33 \\
\hline
\end{tabular}

Note. Own study.

The most important traits to be characterised by entrepreneurial inhabitants of Lublin were: industriousness (4.66), persistence (4.61), ability to work with people (4.60), and creativity (4.45). The least important - willingness to get rich (3.22), tendency to charity (3.28), independence (3.66), and high professionalism (3.99). Among the characteristics of the average rating above 4 are: honesty (4.46), diligence (4.33), and ability to cooperate with people (4.33). The lowest scores were obtained by such attributes as: willingness to get rich (3.24), ability to take risks (3.34), and ability to use opportunities (3.45).

The next two questions were about the conducive and hindering aspects of starting a business. Answers were given on a scale of 1 (little importance) to 5 (high importance). This is presented in Table 2.

Table 2.

Features conducive to and hindering the establishment of one's own company

\begin{tabular}{|l|c|l|c|}
\hline \multicolumn{1}{|c|}{ Features conducive } & \multicolumn{2}{c|}{ Features hindering } & $\begin{array}{c}\text { feature } \\
\text { average } \\
\text { grade/value }\end{array}$ \\
\hline Persistence and consistency in action & 4.58 & Laziness & 4.34 \\
\hline Innovation and creativity & 4.46 & Lack of mental resistance & 4.29 \\
\hline Independence of thinking, independence & 4.31 & Difficulties in making decisions & 4.25 \\
\hline Ambition and the need for achievement & 4.20 & Problems communicating & 4.19 \\
\hline Ability to learn & 3.98 & Pessimism & 4.17 \\
\hline Risk inclination and courage & 3.93 & Lack of life energy & 4.14 \\
\hline Readiness to compete & 3.80 & Difficulties in organising activities & 3.97 \\
\hline Leadership & 3.78 & $\begin{array}{l}\text { Lack of knowledge of running } \\
\text { a business }\end{array}$ & 3.95 \\
\hline Possessing managerial knowledge & 3.58 & Excessive caution & 3.86 \\
\hline
\end{tabular}

Note. Own study.

The respondents' responses show that being an entrepreneur requires a combination of perseverance with imagination, creativity, and with self-reliance and independence that will allow for ambitious goals. Little less do they appreciate the importance of learning and the ability to take risky and uncertain actions. Somewhat surprising is the low assessment of the usefulness of leadership and managerial skills that are essential to play an active role in one's business. Among the most disturbing qualities were laziness, passivity, and indecision, which are in fact incompatible with the entrepreneurial attitude. The negative impact of communication difficulties with other people, a pessimistic attitude to the world and the associated lack of willingness to act were also indicated. Less important obstacles in the respondents' opinion are problems related to possessing knowledge and managerial skills.

Then the respondents were asked if they had been considering starting their own business. 24 people already run their own business, 35 people are considering this opportunity in the near future, while 30 people are not going to become entrepreneurs. The last ones were asked 
to give the main reasons why they did not want to start their own business. These are: no business ideas ( 9 people), there are no conditions for running a business in the Lublin region (4), lack of knowledge (4), satisfaction with full-time employment (4), lack of financial resources (3), too late due to age (3), fear of high risk (3).

Do the respondents consider the terms and conditions of running an individual business in Lublin as adequate? 9 people think that yes definitely, 33 - rather yes, 19 - not quite, 6 - definitely not, and 22 people do not have a say on this topic (these are people who do not intend to start their own company). The respondents also assessed their knowledge on institutions and business support programs on a scale of 1 (no knowledge) to 5 (they have extensive knowledge). It turned out that the best known solutions are entrepreneurial training (average rating 4.24) and educational programs (4.10). Knowledge on entrepreneurship incubators are insufficient (2.66). Consultancy provided by various institutions, agencies, state offices is little known, the average is 2.4. The least known solutions are technology parks (2.2) and business angels (1.92).

Residents who already run their own businesses were asked to indicate what motivates them to start their own business. The respondents assessed motives on a scale of 1 (little importance) to 5 (high importance). The results are as follows:

- independence, ambition, need for self-fulfilment - average rating 4.33,

- business idea - 4.0,

- additional income -3.42 ,

- desire to get rich -3.38 ,

- $\quad$ spotting a market gap -2.92 ,

- no job offers - 2.25,

- loss of current employment - 2.0,

- grants for starting a business -1.92 ,

- using EU assistance programs - 1.50,

- family tradition - 1.08 .

The answer is that entrepreneurial activities were mainly undertaken caused by positive motives - willingness to be independent, realisation of own ideas for business, and selfrealisation. EU support programs and business start up subsidies were rather a complementary stimulus. This is confirmed by answers to the question about the sources of financing, which entrepreneurs used to set up the company: own capital - 19 people, loan from family and friends - 9, credit - 5, EU funds - 2, and District Labour Office -2 .

The respondents-entrepreneurs were also asked to evaluate the barriers associated with starting a business on a scale of 1 (little importance) to 5 (high importance). The following average scores were obtained:

- frequent changes in the Polish law -4.71,

- large taxes and fees -4.67 , 
- risk apprehension - 3.79,

- bureaucracy accompanying the company -3.71 ,

- difficulty entering the market, competition -3.42 ,

- lack of capital to start up own business - 3.25,

- risk of loss in business -3.13 ,

- inadequate knowledge of running a business - 3.08,

- volatility of demand -2.88 ,

- lack of experience in running a company -2.79 ,

- lack of confidence in business success - 2.54,

- fear of excessive time load - 2.46,

- difficulty obtaining a credit -2.42 .

Comparing the answers of the respondents employed on a regular basis and individual entrepreneurs, it should be noted that there are no fundamental differences. Among the mentioned factors conducive and hindering entrepreneurial activity in the first three places are the same answers, differing only in order, with mean scores being very similar. It should also be noted that the most optimistic persons are those who are just going to start a business, in comparison to existing entrepreneurs and people who do not intend to resign from the job. The same is true when evaluating the conditions for running one's own business in the Lublin Region. In the group of prospective entrepreneurs, young people are predominant, aged between 21 and 30 with a Master's degree.

Among people who do not intend to start their own business in the future, the main cause of reluctance depends on age. In the 21-30-year age group it is a lack of a business idea. The respondents aged 31-40 indicate mainly the lack of conditions for running their own business in the Lublin Region. Older respondents are satisfied with the job and they think the change is too late because of the age. It turned out that a lack of financial resources is not a major obstacle. Similarly, in the group of existing entrepreneurs, the main barriers when deciding to start a business are legal and administrative rather than financial.

Individuals who highly value entrepreneurial features (average 4.18) are most likely to start their own businesses. The average rating of own characteristics of respondents entrepreneurs is slightly lower (4.05), while in the group of people who do not intend to start their own company the average rating is significantly lower (3.37). 


\section{Summary}

J. Strojny and B. Stankiewicz treat entrepreneurship as a multidimensional phenomenon, distinguishing four dimensions: economic, social, organisational, and individual. In each of them there are phenomena and processes that condition its development. There are correlating positive relationships between these dimensions. The authors write: "However, it should be assumed that there is a mechanism of business acceleration causing, that the higher the level of entrepreneurship in one dimension, the higher the level of entrepreneurship in other dimensions" (Strojny, and Stankiewicz, 2009, p. 124). The respondents in the presented research do not assess the conditions for starting and running an individual business activity in Lublin very well. This causes more than $1 / 3$ of the respondents not to become entrepreneurs.

T. Piecuch points out that when analysing the internal conditions of entrepreneurship, special attention is paid to the entrepreneur and his or her ability to overcome problems, difficulties, and deal with stress (Piecuch, 2013, p. 86). The respondents' answers confirmed that personality features have a significant impact on the decision to be an entrepreneur; they were first identified as the motivators for starting a business. However, in order for intentions to become acts, external conditions are necessary. They are related to market mechanisms, primarily of stability, as well as the development of banking, financial, tax, and customs systems. They serve as stimulants both in the initiation, conduct, or development of entrepreneurship (Piecuch, 2013, p. 83). The research presented in the article shows that factors conducive to starting an individual business activity are mainly internal factors, or the personality and psychological characteristics of the respondents, their desire to be independent and to realise their own business ideas. The external factors, above all legal and economic, make this process difficult.

\section{Bibliography}

1. Aktywność Ekonomiczna Ludności w województwie lubelskim. Stan w IV kwartale 2014 roku. Opracowanie sygnalne (March 2015). Lublin, Urząd Statystyczny. Retrieved from http://lublin.stat.gov.pl/opracowania-biezace/opracowania-sygnalne/praca-wynagrodzenie/ aktywnosc-ekonomiczna-ludnosci-w-wojewodztwie-lubelskim-stan-w-iv-kwartale-2014r-,3,7.html. Available online 25.06.2017.

2. Glinka, B. (2008). Kulturowe uwarunkowania przedsiębiorczości w Polsce. Warszawa: PWE. 
3. Gołębiowski, G. (2008). Przedsiębiorczość a czynniki społeczno-kulturowe. Problemy Zarządzania, $n r$ 2(20).

4. Gruszecki, T. (2002). Współczesne teorie przedsiębiorstwa. Warszawa: PWN.

5. Haber, L.H. (1996). Zachowania przedsiębiorcze - próba typologii. Przegląd Organizacji, $n r 5$.

6. http://www.bbm.com.pl/metodologia-badawcza/metody-doboru-proby-badawczej/. Available online 25.06.2015.

7. Jędruchniewicz, A. (2011). Makroekonomiczne uwarunkowania przedsiębiorczości. Ekonomika i organizacja przedsiębiorstwa, $n r 3$.

8. Karlsson, Ch., Johansson, B., and Stough, R.R. (2014). Agglomeration, Clusters and Entrepreneurship: Studies in Regional Economic Development. Cheltenham, UK: Edward Elgar Publishing.

9. Kraśnicka, T. (2002). Koncepcja rozwoju przedsiębiorczości ekonomicznej i pozaekonomicznej. Katowice: Wydawnictwo Akademii Ekonomicznej.

10. Lichtarski, J., and Karaś, M. (2003). Pojmowanie przedsiębiorczości i warunkujące ją czynniki. In K. Jaremczuk (ed.), Uwarunkowania rozwoju przedsiębiorczości - szanse i zagrożenia. Tarnobrzeg: PWSZ.

11. Majkut, R. (2014). Przedsiębiorczość w świetle uwarunkowań interdyscyplinarnych. Warszawa: CeDeWu.pl.

12. Mieszajkina, E. (2014). Postawy mieszkańców Lubelszczyzny wobec przedsiębiorczości indywidualnej. In E. Bojar, and E. Mieszajkina (eds.), Przedsiębiorczość $i$ wiedza w kreowaniu rozwoju regionalnego. Lublin: Wydawnictwo Politechniki Lubelskiej.

13. Penc, J. (2001). Strategiczny system zarządzania. Warszawa: Agencja Wydawnicza Placet.

14. Piecuch, T. (2013). Przedsiębiorczość. Podstawy teoretyczne. Warszawa: C.H. Beck.

15. Rollnik-Sadowska, E. (2010). Przedsiębiorczość kobiet w Polsce. Warszawa: Difin.

16. Safin, K. (2003). Zarzadzanie mała firma. Wrocław: Wydawnictwo Akademii Ekonomicznej.

17. Strojny, J., and Stankiewicz, B. (2009). Wielowymiarowa analiza przedsiębiorczości metodologia, narzędzia i znaczenie dla społeczeństwa informacyjnego. Przedsiębiorczość - Edukacja, $n$ r 5.

18. Sudoł, S. (2008). Przedsiębiorczość - jej pojmowanie, typy i czynniki ją kształtujące. Problemy Zarzadzania, $n r$ 2(20).

19. Tarnawa, A., and Skowrońska, A. (eds.) (2016). Raport o stanie sektora MSP w Polsce. Warszawa: PARP.

20. Zieliński, K. (ed.) (2014). Formy i przejawy wspótczesnej przedsiębiorczości w Polsce. Warszawa: Difin. 